This item was submitted to Loughborough's Research Repository by the author.

Items in Figshare are protected by copyright, with all rights reserved, unless otherwise indicated.

\title{
Change and continuity in Bulgaria and Romania's foreign policies post-EU accession
}

\section{PLEASE CITE THE PUBLISHED VERSION}

https://doi.org/10.1080/23745118.2020.1729053

\section{PUBLISHER}

Taylor \& Francis (Routledge)

\section{VERSION}

AM (Accepted Manuscript)

\section{PUBLISHER STATEMENT}

This is an Accepted Manuscript of an article published by Taylor \& Francis in European Politics and Society on 14 February 2020, available online: http://www.tandfonline.com/10.1080/23745118.2020.1729053.

\section{LICENCE}

CC BY-NC-ND 4.0

\section{REPOSITORY RECORD}

Nitoiu, Cristian, and Teodor Lucian Moga. 2020. "Change and Continuity in Bulgaria and Romania's Foreign Policies Post-eu Accession”. Loughborough University. https://hdl.handle.net/2134/11974083.v1. 


\title{
Change and continuity in Bulgaria and Romania's foreign policies post-EU accession
}

Cristian Nitoiu, Institute for Diplomacy and International Governance, Loughborough University London C.Nitoiu@lboro.ac.uk

Teodor Lucian Moga, Centre for European Studies, Faculty of Law, 'Alexandru Ioan Cuza' University of Iasi (UAIC) teodor.moga@uaic.ro

\begin{abstract}
For much of the post-Cold War period the most important foreign policy priority for Bulgaria and Romania was framed by the aim of 'returning to Europe'. The goal to integrate in the European and Euro-Atlantic structures was so pervasive that it dominated the domestic, but more importantly, the foreign policy agendas of the two countries. Securing membership of the European Union (EU) and then preparing for it raised a large number of challenges for the foreign policies of Romania and Bulgaria. Following accession, Bulgaria and Romania have been forced to reframe their strategy, as their main foreign policy goal had been fulfilled. In this context, the article examines the way Romania and Bulgaria's foreign policy priorities have evolved since 2007 . The focus is on analysing the contribution of the two countries to EU foreign policy and accounting for their lack of initiative and activism in this policy area.
\end{abstract}

Keywords: Romania, Bulgaria, foreign policy, European Union, Russia 


\section{Introduction}

For much of the post-Cold War period the most important foreign policy priority for Bulgaria and Romania was framed by the aim of 'returning to Europe'. The goal to integrate in the European and Euro-Atlantic structures was so pervasive that it dominated the domestic, but more importantly, the foreign policy agendas of the two countries. Securing membership of the European Union (EU) and then preparing for it raised a large number of challenges for the foreign policies of Romania and Bulgaria (Bechev, 2009; Bonnemains, 2010; Denca, 2010). These included, for example, developing new expertise in order to deal with the EU, reforming the diplomatic systems that previously catered for cooperation with other Communist states in the setting of the Cold War, learning about and socialising in the context of the EU's decision-making processes, as well as other regional and global multilateral settings, and figuring out of the country's goals and strategy and foreign policy. The latter aspect was arguably the most salient but also the easiest to settle, as embracing European integration as a driving force in their foreign policy strategy meant that relations with the EU and North Atlantic Treaty Organization (NATO) would consume most of the efforts of the two countries in external relations. To that extent, Romania and Bulgaria developed rather unidimensional foreign policies, focusing most of their resources and expertise on securing membership and then preparing the accession period. This came at the expense of other areas and priorities in foreign policy, such as relations with nonWestern regions and states, relations with other multilateral institutions, or issues such as international development (in this case it was more important for them to attract international aid) or climate change. 
Following accession, Bulgaria and Romania have been forced to reframe their strategy, as their main foreign policy goal had been fulfilled. Even though not similar in scale to the transformations that followed the end of Communism, the revision of the two countries' foreign policies after 2007 has focused on a wide range of structures, priorities and expertise. Once part of the EU, Bucharest and Sofia were faced with the task of learning how to act in concert with the other member states, while developing new agendas in foreign policy. Initially, both Romania and Bulgaria tried to frame themselves as experts on the Black Sea region and thus proxies for EU action in this space. However, this article shows that both countries have been less successful in uploading their priorities to EU foreign policies, and have preferred to maintain a rather inactive stance, primarily following the cues of major member states such as France or Germany. This has led to the perception that membership has involved the willing outsourcing of both countries' foreign policies agendas to EU, a sort of self-sacrifice of agency in external relations. In the case of Romania, this process has been overlapped by a tendency to follow closely the cues of the United States (US) and to develop strong transatlantic tendencies. The situation is very much in contrast with the enlargement wave of 2005, where most of the new member states have been very keen to put their mark on the EU foreign policy (Tulmets, 2014). In this context, the article examines the way Romania and Bulgaria's foreign policy priorities have evolved since 2007. The focus is on analysing the contribution of the two countries to EU foreign policy and accounting for their lack of initiative and activism in this policy area - both countries have recently held the presidency of the Council of the EU, Bulgaria in first half of 2018, while Romania in the first half of 2019. While deepening integration, maintaining and developing the transatlantic partnership with the US, as well as investing in NATO have continued to be the main key drivers of the foreign policies of the two countries, 
we are to larger extent interested in shedding light on the way EU membership has influenced Romania and Bulgaria's priorities in other areas (which were only of marginal salience during the pre-accession period). Analysing their approach to the US and NATO, or the foreign policy decision-making processes of the EU are indeed worthy endeavours, but would deserve to form the main focus of a separate publication.

The first part of the article examines Bulgaria and Romania's traditional foreign policy priorities and discusses them comparatively. The comparative focus on Romania and Bulgaria is justified by the fact that both countries shared similar experiences in the lead up to becoming members of the EU, and the Union itself has tended to group Bucharest and Sofia together. Both are examples of small states (we acknowledge that there is considerable disagreement in the literature concerning this concept), whose foreign policies are constrained by their position in the world order, as well as in the decision-making system of the EU. ${ }^{1}$ Moreover, a decade following accession to the EU has been enough time for changes in the foreign policies of the countries to be designed and implemented. The second section focuses on the way the Foreign Policy Analysis (FPA) literature has sought to account for change and continuity in the foreign policy priorities of small states. ${ }^{2}$ The focus is on identifying the policy frames that have shaped

1 At the same time, as the article highlights, in comparison to other member states from Central and Eastern Europe, which faced similar constraints, like Poland or the Czech Republic, Sofia and Bucharest were much more inactive in trying to learn the necessary negotiation skills to shape the EU's foreign policy.

2 Even though there is considerable disagreement in the literature over the actual definition of small states, we argue that a state can be considered small if it has a limited ability to influence the international agenda (Maass, 2009). There are various ways of classifying small states according to their characteristics, and Romania and Bulgaria's capabilities in some areas may very well point to the potential to punch above the weight of a small state. Moreover, we argue that the various features 
the development, design and implementation of ideas and priorities in the foreign policies of the two countries. By focusing on official documents and statements, frame analysis also allows for identifying the key strategies used by the both states in foreign policy. To that end, the article analyses a wide range of official documents and statements starting from the end of the Cold War (with a focus on the post-accession period). The next two sections look respectively at how Bulgaria and Romania have acted regarding their key foreign policy priorities following accession to the EU. The article concludes with a discussion of the rather inactive approach that both countries have adopted since being members of the EU.

\section{Bulgaria and Romania's foreign policy priorities}

The end of the Cold War and transition to democracy forced countries like Bulgaria and Romania to rethink and redesign their foreign policies. For much of this period the most important policy objective was securing membership of the EU and NATO. Hence, most foreign policy transformations have tended to serve this goal. This involved creating viable foreign policy institutions, developing expertise and human resource, learning how to interact with other states and international organisations, together with non-state actors such as multinational companies or terrorist groups, and figuring out their foreign policy priorities and the range of norms and values that would underpin

identified by the literature, such as size, population, economy, military weight are essential when differentiating a small state (including Romania and Bulgaria) from a great power. For instance, according to Copsey \& Haughton (2009) size determines dependency on institutions/international organizations (such as the EU) to compensate for their external limitations. However, as this article highlights both countries have framed their identity in world politics as small states, a perception which underscored their inactivity in foreign policy and meagre ability to influence the international agenda. 
their behaviour in international relations. All these processes were synchronised with state building projects, and in some cases intense domestic battles for political power or the creation of flawed democratic regimes.

While European and Transatlantic aspirations have captured most of the foreign policy agendas of the two countries, Bulgaria and Romania share several other priorities (which are briefly presented in the remainder of the section). Firstly, both states have had to devise new relationships with Russia following the end of the Cold War. Second, both states have been rather active in the development of Black Sea regionalism, fostering various initiatives, such as the Black Sea Synergy. Third, Bulgaria and Romania have been keen to share their accession experience with the candidate states in the Western Balkans and support their membership. Fourth, both countries have shown a deep interest in helping the development and democratisation processes of the former post-Soviet states. The next section focuses on the way the FPA literature has aimed to account for and analyse changes in the foreign policies of small states like Romania and Bulgaria.

\section{Small states' foreign policies: Romania and Bulgaria}

The FPA body of literature tends to treat countries like Bulgaria and Romania as examples of small states - even though there is intense disagreement regarding the concept (Väyrynen 1971; Maass, 2009; Thorhallsson and Steinsson 2017). States are generally classified as small due to their population, territory, natural resources or place in the hierarchy of international relations - i.e. not being a great power. Most empirical studies focusing on domestic factors tend to centre on the case of small European states (most times EU member states such as Denmark, Finland, or the Netherlands) and the 
way they manage to shape the agenda in world politics. The overarching finding here is that small European states have to adapt their foreign policy institutions, priorities and norms according to those of the EU in order to have the opportunity to advance their national interests and set the agenda. Hence, learning the ropes of the EU foreign policy and then shaping it, has been a proxy for achieving greater effectiveness in foreign policy for small European states (Jakobsen, 2009; Marcussen, Wivel, and Miles 2011; Toje 2011; Nasra 2011). For example, Poland adapted its foreign policy institutions, priorities and resources after accession and managed to successfully shape the EU's policy towards the post-Soviet space (especially Ukraine) - with the creation of the Eastern Partnership (EaP) a key outcome (Copsey \& Pomorska, 2013). In the same vein, the Baltic countries have sought to play a key role in the Euro-Atlantic community's relations with the EaP states by adapting the design of their new foreign policy after 2004 in order to cope with the former Soviet space (Galbreath \& Lamoreaux, 2007; Kesa, 2011; Pastore, 2013).

The FPA tradition and the body of literature on the foreign policies of small states generally focus on building a narrative about the way priorities are constructed and then change in time. In this article, we aim to go beyond that by analysing the strategic framing activities of the post-Communist states in foreign policy. Strategic framing allows political actors to articulate their discourse or policies, getting them across to various actors (Rhinard, 2010; Schultz, et al., 2012). In turn, the method of frame analysis helps to identify the way in which the discourse of political actors is categorised around a series of central opinions and ideas. Hence, analysing frames allows understanding the strategies used by Romania and Bulgaria in order to define their foreign policies priorities in shaping the EU's foreign policy. More generally, frame analysis underscores the connections made between different events, policies or 
phenomena in constructing and politicising discourse or policies (Entman, 1993). Here the analysis will be based on triangulated data collected through the analysis of speeches, official documents and background interviews with policymakers. Frame analysis allows us to identify the way the key priorities in the foreign policies of the two countries have been transformed by the accession to the EU.

\section{Bulgaria}

\section{Relations with Russia}

Bulgaria's accession to the EU prompted various analysts to argue that the country would play the role of a Trojan horse and try to support Russian views and interests in shaping the EU's foreign policy. This view was based on the long tradition of close relations between Sofia and Moscow, as well as Bulgaria's tendency to balance between the interest of the West and Russia during the post-Cold war period. The memory of the liberation of Bulgaria from the Ottoman yoke still plays an important part in the Bulgarian society and influences favourable views towards Moscow. Even through Bulgaria has cultivated close relations with Russia, primarily due the Slavic and Orthodox shared heritage, at various times in history, leaders in Sofia have snubbed the Kremlin, siding with states or alliances conventionally seen as anti-Russian (Bechev, 2009; 2015). Nevertheless, out of all the post-Communist states, Bulgaria has framed one of the most important priority in its foreign policy to keep Russian fears at bay regarding its integration into NATO or the EU. This balancing act, however, has not made Bulgaria a Russian Trojan horse in the EU. In the last decade, Bulgaria's multivector foreign policy has translated in moderate to insignificant influence and 
agenda setting when it comes to the EU's approach to Russia or the post-Soviet space (Stoeva 2014). Bulgarian leaders might have been driven by the thought that inactivity will not endanger their country's relations with Moscow or position in the EU (Clark and Foxall, 2014). To that extent, Bulgaria has framed its behaviour more as a pragmatist rather than Trojan horse, aiming to preserve good working relations with Russia, while signing on to the EU's approach toward Moscow.

Nevertheless, in the last years there are two key examples where Bulgaria has deviated from its pragmatic and balanced approach towards Russia in the EU. The most important refers to the ongoing Bulgarian support for sanctions against Russia following the Ukraine crisis. Despite the EU sanctions regime, Russia has remained one of the top three trade partners for Bulgaria when it comes to energy resources, while it is in the top 10 on other exports; there is also an asymmetric trade balance between the two countries which is tilted towards Russia. ${ }^{3}$ The industry affected the most has been tourism, with the annual number of Russian tourists visiting Bulgaria decreasing by $25 \%$ from 2013 to $2018 .^{4}$ There is wide ranging cross parliamentary support for improving relations with Russia, with current president Radev trying to balance between rapprochement with Russia and maintaining what is widely seen as an appropriate stance in the EU and NATO (Novinite, 2018). Even though most political parties in Bulgaria do not favour maintain sanctions against Russia, the government in Sofia has continued to follow the common position of the member states.

Bulgaria has indeed agreed to the sanctions imposed on Russia, however it has not fully internalised the frame that vilifies the Kremlin and the narrative that Moscow

\footnotetext{
${ }^{3}$ See http://www.bnb.bg/Statistics/StExternalSector/StForeignTrade/StFTExports/index.htm

4 See http://www.tourism.government.bg/bg/kategorii/statisticheski-danni/statisticheski-danni-zamezhdunaroden-turizum-v-bulgariya-za-2018-g
} 
is the biggest threat to European security. Out of all the post-Communist EU member states, Bulgaria has been the most reluctant to take part of the reinforcement of the socalled 'Eastern front' ${ }^{5}$. Framing Putin and Moscow as the most important threat and source of instability for the EU, has not been supported by Bulgaria, but at the same time, not opposed in a vigorous manner (Kurečić, 2017). Contradictions between Bulgarian and European leaders have appeared more at informal level rather than surfacing in the public space. As discussed below, Bulgaria has shown interest in the EU's eastern neighbourhood and has tried to help the countries in the region progress on their path to European integration. However, it has been careful in supporting initiatives only when they did not conflict with Moscow's interests. In practice this has meant that Bulgaria has been rather inactive in shaping the agenda of the EU's policy towards the Eastern neighbourhood. That being said, Russian soft power is currently at work in Bulgaria, especially through the ties between the two respective Orthodox churches (Slavov, 2017). At the same time, many Russian businessmen have invested in Bulgaria, especially in the real estate sector, as well as the energy one. This web of business ties has the potential to spill over to the political sphere and translate into influence on Bulgaria's political landscape and decisions, as well as the countries behaviour in the EU (Bechev, 2015).

During the decade of EU membership, Bulgaria's has generally followed the cues of the European Commission when it comes to energy security, even though on the surface this has been at times framed against Sofia's interests: e.g. the case of the South Stream project. Bulgaria supported initially the South Stream project due to the fear of lack of solidarity among EU member states, similarly to what happened during the

\footnotetext{
${ }^{5}$ See Bulgaria's National Security Strategy. Retrieved from: https://www.me.government.bg/files/useruploads/files/national_strategy1.pdf
} 
energy crises in 2006 and 2009. Together with Italy, it initially indicated support for the exemption of South Stream from the EU, drawing criticism from countries like Poland or Romania. Moreover, Sofia's balancing approach towards Russia provided additional drive for trying to act as the pipeline's entry in the EU. Faced with a penalty procedure from the EU, Bulgaria, however, froze the project in July 2014, which made Putin significantly angry and disappointed with the government in Sofia (Franza 2015). The halting of the South Steam project, as well as the suspension of the Nabucco pipeline project has meant that countries in the Balkans continue to be dependent on Russian gas which transits through Turkey.

\section{The Black Sea region}

In the build-up to accession and shortly after it, Bulgaria tried to spearhead the EU's approach towards the Black Sea region. Similar to Romania, Sofia framed the need to develop the Black Sea Synergy initiative within the EU and itself becoming (as in the case of the Western Balkans) one of the main EU proxies for dealing with the region. The broad goal was to create a distinct foreign policy identity and rationale for Bulgaria which would allow it to set the agenda in the EU foreign policy. Both in the political sphere as well in the academia and think tank world, Bulgaria framed a series of ideas and strategies for how the EU should manage the Black Sea region and promote its integration project. Various academic conferences were organized, while the government and various think thanks came up with reports and white papers outlining the Bulgarian strategy for the region. Developing Black Sea regionalism was seen as a way of stabilising the area and strengthening links between the member states and the neighbours (Manoli, 2011). Bulgaria also argued that any initiatives in the Black Sea 
region should take into account the interests of the countries in the region, both those seeking to integrate in the EU, as well as more major actors such as Russia and Turkey. At the same time, Sofia framed the need to develop civil society and has hosted several NGO forums focusing on the Black Sea region (Novinite, 2010).

From the Bulgarian perspective, Turkey represents one of the most important actor in the Black Sea region. Moreover, the presence of a Turkish minority on its territory has meant that Bulgaria has not always had the smoothest relations with its larger southern neighbour. ${ }^{6}$ Recently, Bulgaria has also had to adopt a rather careful approach towards Turkey, especially due to the migrant crisis, Ankara's mixed approach to NATO in the Black Sea, or the authoritarian developments in Turkey. To that extent, Bulgaria has generally been a supporter of Turkish membership in the EU, for example, in recent years denying that it would support a potential freeze of the accession negotiations with Turkey (Gotev, 2016). At the same time, Bulgarian politicians have sometimes argued that a veto to Turkey's membership should not be discounted, if real progress is not achieved in shared issues in water and energy management (Radio Bulgaria, 2010) - nevertheless, the Bulgarian government has continued throughout the last decade to support the accession negotiations with Turkey. In terms of migration, Bulgaria framed its track record in managing the border with Turkey and significantly reducing in the year following the agreement with Ankara migration pressure. The Bulgarian presidency of the Council of the EU aimed to employ a pragmatic approach to Turkey, security the implementation of the agreement. ${ }^{7}$

\footnotetext{
${ }^{6}$ See https://www.mfa.bg/en/news/18741

${ }^{7}$ See priorities of the Bulgarian presidency of the Council of the EU.
} 


\section{Western Balkans}

Bulgaria has tried to frame itself in the EU as one the key supporters of the integration of the Western Balkans, as well as a member state with significant expertise on the region. Following Poland's example, the rationale was that due to its expertise and contacts in the region, Bulgaria would become one of the EU's main points of call for its policy in the Western Balkans. Bulgaria followed the cues of the European Commission and Germany or Austria regarding the Western Balkans in order to show that it behaves as a good student and it is worthy of the task to spearhead the EU's policy in the region. This has translated, for example, in the fact that even though Bulgaria tries to maintain good relations with Serbia, unlike Romania it has chosen to recognise and support Kosovo's independence. The main country in Western Balkans where Bulgaria has tried to influence domestic developments and the path to European integration is Macedonia. The two countries indeed share a degree of cultural and historical heritage; however, Macedonia has made strides in developing a distinct national identity. Bulgaria has tried to act as a supporter of Macedonia's aspirations for European integration and has even been encouraging the use of its name despite Greece criticism. Moreover, since Zoran Zaev became PM in Macedonia in 2017 his personal relationship with the Bulgarian PM Borisov led to the fast improvement of relations between the two countries. ${ }^{8}$ While on the surface Bulgaria brands itself as a supporter of the Western Balkan countries' desires to integrate in the EU, Sofia has often put various conditions on advancing negotiations with Macedonia: e.g. demanding for progress in cross-border cooperation or the establishment of an intergovernmental

\footnotetext{
${ }^{8}$ See more details about their relationship here: https://europeanwesternbalkans.com/2019/02/05/zaevborisov-meet-sofia-discuss-economic-cultural-cooperation/
} 
council (Kojouharov, 2011). There is a fear that if the Western Balkans would not join the EU soon, Macedonia might slip into a deep political and economic crisis which could potentially spill over to Bulgaria. Moreover, Sofia could lose its influence due to the efforts of countries like China, Turkey or Russia who might try to have a more important role in the area.

Bulgaria held the presidency of the Council of the EU in the first semester of 2018. The central frame of the Balkan presidency was the idea that the EU was the most appropriate avenue to deliver a series of public goods to citizens in the Balkans. Before assuming the presidency, Bulgarian officials travelled through the Western Balkans, and assured leaders in the region that supporting their countries' membership aspirations would be Bulgaria's main objective during the six-month period. However, during the presidency the official rhetoric of the government was quite neutral in this regard, arguing that it aims to 'achieve a clear action plan with each of the countries, without creating unrealistic expectations but with concrete steps' (Chobanova, 2018). This might be seen as evidence of learning and socialisation on the part of the Bulgarian presidency, as its ambitions objectives had to be aligned with the more pragmatic approach from the Commission once leaders in Sofia were faced with the realities of acting in Brussels and dealing on behalf of the EU. In May 2018, the Bulgarian presidency spearheaded the first summit in 15 years that reunited the six Western Balkans countries, with the goal to advance their bids for EU membership. ${ }^{9}$ Even though not all the EU member states attended the summit, and there was considerable disagreement, especially with regard to Kosovo, the meeting was key to highlighting Bulgaria's claim of its presiding being a 'Balkan presidency of the EU'.

\footnotetext{
9 See the conclusions of the summit: https://www.consilium.europa.eu/en/meetings/internationalsummit/2018/05/17/
} 


\section{The post-Soviet space}

A key priority of Bulgaria within the EU's foreign policy has been to promote the extension of the European integration project to the countries of the post-Soviet space. Sofia has paid special attention to Moldova and Ukraine, offering them administrative support in their efforts to implement various reforms. During the 2015 revision of the European Neighbourhood Policy (ENP) Bulgaria was an important advocate of giving increased voice to the neighbourhood states, and tailoring initiatives towards the region based on the need of these countries rather than the EU's own interests. This frame translated into the principles of differentiation and greater ownership for the neighbours, which were a centre piece of the revised ENP (European Commission, 2015).

During the Ukraine crisis, Bulgaria slightly abandoned its balanced approach and sided with the other member states in condemning Russia's aggression and imposing sanctions on Moscow. To that extent, Bulgaria has supported the Association Agreement (AA) and Deep and Comprehensive Free Trade Areas (DCFTA) with Ukraine (as well as Moldova and Georgia). Nevertheless, as the Ukraine crisis has increasingly morphed into a frozen conflict, leaders in Sofia have also slightly softened their critical language towards Russia and have avoided supporting within the EU even more conflictual policies towards Russia (Tsolova, 2017). Bulgaria has joined a whole host of member states that aim to defuse the tensions with Russia (e.g. Italy or the Czech Republic). This, in turn, has attracted criticism from member states that represent key pillars of the so-called 'Eastern flank' (e.g. Poland or the Baltic states). The annexation of Crimea and the whole Ukraine crisis highlighted the need for the 
Bulgarian government to design a coherent and consistent foreign policy towards the Black Sea region, decrease the EU's dependence on Russian energy, as well as making the EU's neighbourhood less dependent on Russia and supporting their European integration ambitions (Ralchev, 2015, p. 123).

From 2010 to 2013, under the leadership of former foreign affairs minister Nickolay Mladenov, Bulgaria's foreign policy underwent a process of reform and renewal, with many former Communist diplomats and bureaucrats being replaced, while the country supported the EU's approach towards the neighbourhood. Nevertheless, Bulgaria is still lacking human capacity and expertise when it comes to influencing in a positive manner the EU's foreign policy towards the neighbourhood (Ralchev 2015, 132). More recently, due to its dualism and balanced approach, Bulgaria has been rather unwilling to support wholeheartedly EU initiatives in the neighbourhood that have posed significant risks to Russian interests (NEOnline, 2017). Nevertheless, Bulgaria has identified an opportunity for creative lucrative economic relations with Ukraine and Moldova following the signing of the AA and DCFTA. Ukraine presents important opportunities due to its large market, while in Moldova, Sofia can operate in the absence of the level of suspicion that Romania's actions usually attract. At the same time, the presence of a Bulgarian minority in Ukraine has meant that the country has paid significant attention to the Ukraine crisis. Bulgaria often declared its support for the democratisation process of Ukraine, as well as for the need to develop inclusive partnership with the EU's neighbours. In this regard, Bulgaria framed the need for the revised ENP to be more effect and result-oriented, while also stressing the need to develop a mix of policy areas such as energy security, institutional reforms or the fight against terrorism (European Commission, 2015). 


\section{Romania}

\section{Relations with Russia}

Unlike Bulgaria, Romania has maintained during the last decade an extremely critical and outspoken attitude against Russia's actions. Most importantly, Bucharest has criticised Moscow's engagement in Moldovan domestic affairs and the way the Kremlin uses energy prices to manipulate the domestic agenda of other countries. Former President Băsescu is famous for arguing that the Black Sea should not be turned into a Russian lake (Nitoiu, 2015). After the Georgian-Russian war of 2008 the Romanian Foreign minister stated that Moscow was a 'dormant volcano' which could erupt at any point in the future, and the EU had the duty to protect the territorial integrity of its Eastern neighbours in such an eventuality (Nitoiu, 2015). During the Ukraine crisis, Romania received injured protestors from the Maidan and condemned the annexation of Crimea (Pavlenko et. al 2014) - Bulgaria also received a smaller number of protestors. Romanian policymakers also framed the need for a stronger EU and NATO presence in the Black Sea which would counter Russia's moves. On the other hand, Micu argues that while former President Băsescu's actions towards Russia can be considered daring, they reflect an overall distrust found in the Romanian public sphere towards Russia (Micu, 2013, p. 199). Leaders in Bucharest have been more than once frustrated by the differential gas prices that Gazprom uses. Support for an alternative route for gas that could short-circuit Russia became in the initial phase of the enlargement one of the main foreign policy goals that Romania was to pursue within the EU. As such, Romania framed itself as one of the most fervent supporters of the failed Nabucco project (Gotev, 2013). Romania has also been frustrated by the lack of coordination and solidarity in the 
EU regarding Russia. Romanian policymakers equated the EU's weak policy towards Moscow with the big member states' purely self-interested ties with Russia, which disregard the interests of the new member states (Nitoiu, 2011).

Besides the energy sector where Romania imports between 10 and $20 \%$ of its needs from Russia, since the fall of Communism economic relations with Moscow and have also been poor. A head to head competition for Gazprom's favours was launched between Romania and Bulgaria, the prize consisting in hosting the failed South Stream pipeline project (Euractiv, 2010). Together with this new energy cooperation, since accession Russian capital has been invested in the Romanian heavy industry. Before the Ukraine crisis, the Romanian government framed the idea of constructing a strategic partnership with Russia which would assure stability and security in the region (Băsescu, 2008). While this view did not mirror a widely shared consensus among Romanian policymakers - some of which still shared deeply antagonistic feelings towards Moscow - it fitted at the time into to the overall approach of the EU, which the Romanian government was officially committed to. Nevertheless, following the Ukraine crisis, Romania has generally followed the lead of Germany and France in imposing sanctions on Russia and freezing relations with Moscow, framing Russia as one of the biggest threats to the EU.

\section{The Black Sea region}

At the multilateral level, Romania attempted to raise its own profile in the Black Sea region by launching in 2006 the Black Sea Forum for Partnership and Dialogue (BSF), a framework for enhancing regular consultation and generating sectoral-cooperation opportunities among the Black Sea riparian states. However, this rather loose and 
informal initiative did not manage to muster sufficient support from the participant states and soon after it was abandoned (Angelescu, 2011, p. 138). Yet, the Romanianmade project has not remained unnoticed, since Romania managed to raise awareness by framing the importance of this region for the EU (Denca, 2013, p. 183). Subsequently, the European Commission elaborated in 2007 a new strategy, branded the Black Sea Synergy (BSS), whose goal was to encourage regional development and address economic and political challenges existing in the countries surrounding the Black Sea (European External Action Service, 2016). Romania has been a vocal supporter - together with Bulgaria and Greece - of the creation of BSS, which was also seen as a supplementary working format trying to solve the region's frozen conflicts in Transnistria, Abkhazia, South Ossetia and Nagorno-Karabakh. Even after 2009, when the BSS was overshadowed by the newly EaP initiative, Romania stepped up its efforts to be framed as a spearhead of the EU in the region (Ivan, 2012, p. 165). As such, it became one of the main sponsors of the Black Sea NGO Forum dedicated to fostering collaboration between the NGOs in the wider Black Sea region and supported the launch in 2010 of the European Commission's initiative 'The Black Sea Partnership for Environment' aimed at protecting the Black Sea against pollution (Romanian Ministry of Foreign Affairs (RMFA), 2018a).

The Danube region as a constituent area of the Black Sea region scores also high on Romania's foreign policy agenda, since it has been included among the current dossiers of the Romanian diplomacy (RMFA, 2018b). The Danube region is framed as having a key role in the development of the national economy, of the trade and infrastructure links with Western Europe. As such, Romania (together with Austria) has been one of the leading contributors to the European Union Strategy for Danube region, elaborated by the European Commission in 2010, which aims at deepening cooperation 
between the riparian states in various spheres such increased transport connectivity, enhancing prosperity, better governance and environmental protection (European Commission, 2010, p. 6). Romania has a strong interest in the development of the strategy, since many Romanian counties bordering the Danube, in the southern part of the country, are amongst the least developed economically and could benefit directly from the EU funds available through this new EU policy (RMFA, 2018c).

\section{Western Balkans}

In the Western Balkans Romania has generally been hewing to the EU political decisions. Bucharest continued to be involved post-2007 both with military personnel and technical expertise in peace-keeping missions and post-conflict reconstruction. As a contributor to the EU's Common Security and Defence Policy (CSDP) missions, Romania has deployed military troops in Bosnia and Herzegovina, where the EU-led Operation Althea has been in place since 2004, while in Macedonia (EUPOL Proxima) and Kosovo (EULEX) Romania maintained an active presence until 2005 and 2011, respectively. However, the legal status of Kosovo remains a thorny issue for Romanian diplomacy, since Bucharest, alongside with other four EU member states (Spain, Slovakia, Greece and Cyprus) opposes Kosovo’s independence. This has precluded the EU from adopting a unified position on the issue. The Romanian government has constantly argued, in this regard, that Kosovo's unilateral declaration of independence from Serbia in 2008 contradicts the principles of international law and warns about the consequences such precedent can produce internationally (RMFA, 2018d). The decision not to recognize Kosovo has been framed based on both domestic and external reasons: internally, Romania has been wary that Kosovo's achievement of full statehood could 
harness separatist claims from the Hungarian community living in central Romania, whereas externally Romania feared that the Kosovo precedent might be also applied in the protracted conflicts from post-Soviet Eastern Europe - particularly in the breakaway region of Transnistria in the Republic of Moldova (Linden, 2009, p. 278).

\section{The post-Soviet space}

The Eastern dimension of the ENP has benefited most from Romania's attention. By sharing its borders with two of the six eastern neighbourhood countries (namely, Moldova and Ukraine), Romania has secured since 2007 a key position at the EU's eastern frontiers. In fact, with EU membership, Romania has framed the need to consolidate its 'eastern vocation' as one of its main foreign policy goals (Angelescu, 2011, p. 124). Thus, in the past years the EaP - specially designed to enhance cooperation with the post-Soviet states from Eastern Europe - has become a top priority for the Romanian diplomacy (RMFA, 2018e). Yet, Russia's counteractions in the shared neighbourhood, starting with the brief Georgian-Russian war in 2008 and culminating afterwards with the regional turmoil ignited by the Ukrainian crisis in 2014, have raised additional challenges for the European security (and implicitly for Romania). Given its complicated historical relations with Russia, Romania has always been wary about Moscow's actions in Eastern Europe. Moreover, Romania's participation in the EU and NATO has been framed by the strategy of aligning Bucharest's foreign policy options with the ones of its Western allies, which often collided with Russia's interests in the region. Romania favours in general a more coherent and coordinated engagement at the level of all the EU member states in solving the Ukrainian crisis. In line with the EU's stance, Romania has strongly 
criticized the illegal annexation of Crimea by the Russian Federation in 2014 (RMFA, 2018f). The latest National Defence Strategy (NDS) released in 2015 frames the menacing effects of Russia's disruptive actions in the Eastern neighbourhood (Presidential Administration, 2015, p. 12), while acknowledging the fact that

'regional instability limits Romania's ability to promote its strategic interests, especially those regarding supporting Moldova's European route, solving the frozen conflicts, ensuring energetic security, protecting the rights of the Romanian communities and of the economic activities performed in the Exclusive Economic Zone of Romania at the Black Sea' (Presidential Administration, 2015, p. 15).

Apart from the political and economic support envisaged for the EaP states, Romania currently participates in three training, monitoring and advisory missions in the Eastern neighbourhood: in the EU Border Assistance Mission to Moldova and Ukraine (EUBAM), in EU Monitoring Mission to Georgia (EUMM) and in the EU advisory Mission to Ukraine (EUAM).

At the bilateral level, Moldova and, later on, Ukraine have been the most important recipients of Romania's foreign policy endeavours. First, considering the tight linguistic, cultural and historical ties, Romania's affinity towards Moldova has been evident. In fact, the relationship between the two countries was guided by the 'one nation - two states' principle, clearly spelled out in the 2006 NDS (Presidential Administration 2006, p. 22). With EU accession, the integration of the Moldova into the EU structures has become one of Romania's explicit and constant foreign policy goals. Former President Traian Băsescu took this strong commitment even forward militating 
for the symbolic 'reunion' between the two countries under the aegis of the EU (Presidential Administration 2006b, 2006). Such actions vexed the Communist party ruling Moldova since 2001 and strained diplomatic relations. Strong cooperation between Romania and Moldova only resumed after the civil unrest, which occurred in Chisinau in 2009, toppled the Communist regime and replaced it with the Alliance for European Integration. The strong support for the Republic of Moldova's European integration was reiterated again in the 2010 NDS (Presidential Administration 2010, p. 16), while during the same year the Romanian government approved a non-refundable financial package of 100 million Euros to Moldova, linked to the implementation of reforms (Romanian Ministry of Regional Development and Tourism, 2010). Yet, the paradox for Romania is that despite an active presence in the post-2009 Republic of Moldova, the latest Moldovan presidential elections (November 2016) have shown Romania's limited role in shaping Moldova's pro-European path. The current president of Moldova, Igor Dodon, won the elections on a strong anti-European, anti-unionist platform, choosing instead to build stronger ties with Russia. The latest political developments from Moldova led to a process of rethinking relations between the two countries at the level of the Romanian foreign policy establishment. Under the coordination of president Iohannis, the Romanian Supreme Defence Council (2016) approved in the same month a medium to long term action plan aimed at reassessing the status of relations with Republic of Moldova.

Second, in relation to Ukraine, Romania has not played an active role at the bilateral level and initially limited its actions to the EaP framework. Following the collapse of the Soviet Union, relations between the two neighbours have been rather glacial, characterised by an increased level of mutual mistrust, since issues such as territorial disputes, the protection of the Romanian minority in Ukraine, etc. were still 
unsolved (Dąborowski \& Iwański, 2016). Moreover, in the past Romania failed to view Ukraine as anything else but a state subservient to Russia (Ghinea, 2015). Only after the commencement of the Ukraine crisis has Romania actively supported Ukraine. Romania vocally condemned Russia's annexation of Crimea and its lent support to the pro-Russia rebellion in the Donbas region. Moreover, since September 2014 the Romanian Secret Services have been in charge of the expert team monitoring the overhaul of Ukraine's cybersecurity in the context of the growing tensions between Russia and Ukraine (RMFA, 2018g).

\section{Discussion: A mix of pragmatism, inactivity and outsourcing}

Following their accession to the EU, both Bulgaria and Romania have been forced to redesign their policy priorities as they had achieved their most important goal: i.e. the EU membership. In this context, the article aimed to take stock and analyse the way the foreign policies priorities of the two countries have evolved during the last decade of membership. In analysing change, the article drew on the FPA literature and engaged in frame analysis in order to show the strategies used by the governments in Sofia and Bucharest in order to underline and promote their foreign policy priorities. Rather than gaining more agency in foreign policy, both countries have sunk into a rather dormant state, which has implied inactivity and following the cues of major EU members such as Germany and France or the European Commission. Even though both have refocused their energies on a series of shared foreign polices priorities, their track record of shaping the EU's agenda in relations to the policy issues has been modest at best. This points to a practice of willingly outsourcing of foreign policy (to both the EU and the US), where both states have found it more beneficial to withdraw from an active stance 
in foreign policy and acting as followers in the EU and the broader Transatlantic community.

In the case of Bulgaria, balancing between the West and Russia has been one the foreign policy approaches and behaviour during the post-Cold War period. This is based both on historical and cultural ties with Russia, with the concept of balance being a staple of practice and strategic thinking in Bulgarian foreign policy. Nevertheless, one might argue that accession to NATO or the EU mean that Sofia has shifted altogether towards the West and has abandoned its balancing approach. It is true that in the buildup to its accession, Bulgaria (as well as Romania) had to embark on a series of democratic reforms that had a deep impact on its domestic political context, as well as their foreign relations and interactions with Russia. However, post-accession, Bulgaria has adopted a more pragmatic behaviour in foreign affairs. This happened because the carrot of membership disappeared, and the degree of Europeanisation of Bulgarian political elites was much lower than in the case of those from Poland, the Czech Republic or the Baltic countries. Thus, Bulgaria has been rather inactive and pragmatic in foreign policy, but has aimed to diversify its relations with various actors such as Russia, Turkey or China, at times outside the 'acceptable' framework of a common EU foreign policy.

Pragmatism has also translated in a larger emphasis on the principle of sovereignty and non-intervention in the internal affairs of other states. Similarly to Romania, due to the various criticisms regarding Bulgaria's state of the implementation of reforms in the justice system, as well as allegation of corruption and illiberal politics from EU elites, Sofia has increasingly started to incorporate in its foreign policy the need for other states and institutions to respect Bulgaria's independence and the principle of non-interference. Paradoxically the last decade of ceding sovereignty to the 
EU has made Bulgaria's positions increasingly allergic and reactionary to criticism from the EU elites (the same process is also occurring in the case of Romania). Discussions about the need to take back control or preserve the country's sovereignty are of course not unique to Bulgaria or Romania, but have spread through the post-Communist EU member states, with the Visegrad states even achieving some level of foreign policy coordination in this regard within the EU. From the exterior Bulgaria's (and Romania's) sovereignty discourse, as well as the narrative blaming foreign intervention from figures like Soros, can be perceived to be transplanted from Russia, where this type of rhetoric has been employed for more than a decade. However, rather than a clear result of Russian foreign policy, it is more the consequence of copying Russia's actions, as elites in Bulgaria and other post-Communist member states have noticed the effectiveness of employing such discourse in their goal to strengthen their domestic positions.

Romania's gradual adaptation to the EU requirements had begun even before receiving the candidate status in 1999, at the European Council in Helsinki, considering the fact that the South-Eastern European country expressed its will to join the European structures in the first years after the fall of the Nicolae Ceaușescu's regime. Nevertheless, incorporating the European acquis and institutions in the field of Common Foreign and Security Policy, alongside with the set of norms and values the EU is projecting externally, has proven especially challenging for the former Communist state. The literature studying the relationship between the EU and the Eastern European states is very rich and discusses in detail the EU's expectations and conditions applied to the candidate states from the region, on the one hand, and the limits to the EU conditionality, on the other (Grabbe, 2001; Papadimitriou and Phinnemore, 2004). The Romanian case made no exception, since implementing many reforms in a short amount of time was not an easy task for the young Romanian 
democracy. Post-1999 the adaptation process accelerated to ensure quick integration into the Western structures, namely, the NATO and EU, which occurred in 2004 and 2007, respectively. The Westernization/Europeanization process has had a huge impact over Romania, as the country radically altered its domestic and external policy outlook after more than four decades behind the Iron Curtin.

The deep transformative process underwent by Romania took the shape of an intense socialisation to the EU's norms and values at various levels - institutional, strategic and policy-making. This process has not been an easy task, since the fullfledged membership of the EU required some substantial rearrangements both domestically and internationally. Institutionally, taking on membership requirements meant legal and organisational changes which took years to bear fruit. Strategically, important shifts in policies and orientations were required. Compared to the early 1990s', when ambiguity still dominated Romania's foreign policy doctrine, in the post2007 period the Euro-Atlantic community was considered Romania's the main security linchpin of Eastern Europe. Perhaps the most conclusive test against which the maturity for Bulgarian and Romanian foreign policy establishment came with their recent presidency of the Council of the EU. At the time of writing, Bulgaria had concluded its presidency and the Romanian one was in its initial stages. While Bulgaria, tried to play an active role in supporting the European integration aspirations of the Western Balkans states, throughout its presidency it almost reproduced the mainstream pragmatic message of the European Commission. Bulgaria put a lot of work in the build-up to its presidency in framing its presidency as a Balkan one, that could give more agency to the states in the region. As the article highlighted, Bulgaria ended up as a follower and purveyor of mainstream discourse, having only limited impact of the EU's agenda in foreign policy. Given that Romania has been torn by domestic upheavals during the last 
2 years and has afforded only limited attention to foreign policy issues in the build-up to its 2019 presidency, it is highly likely that it will have an even more modest track record of influencing the EU's agenda.

\section{Acknowledgements}

This work was supported by a grant of the Ministry of Research and Innovation, CNCS

- UEFISCDI, project number PN-III-P1-1.1-TE-2016-0073, within PNCDI III.

\section{References}

Angelescu, I. (2011). New Eastern Perspectives? A Critical Analysis of Romania's Relations with Moldova, Ukraine and the Black Sea Region. Perspectives, 19(2), $123-142$.

Băsescu, T. (2008). Press Statement. The Administration of the President of Romania. Retrieved from http://presidency.ro/index.php?_RID=det\&tb=date\&id=10163\&_PRID=search.

Bechev, D. (2009). From Policy-Takers to Policy-Makers? Observations on Bulgarian and Romanian Foreign Policy Before and After EU Accession. Perspectives on European Politics and Society 10(2), 210-224.

Bechev, D. (2015). Russia's Influence in Bulgaria. Brussels: NEW DIRECTION. Retrieved from $\quad \underline{\text { http://europeanreform.org/files/ND-report- }}$ RussiasInfluenceInBulgaria-preview-lo-res_FV.pdf.

Bonnemains, M. (2010). Romania's Post-Cold War International Relations. Paris: Academie de Paris. Retrieved from https://tel.archives- 
ouvertes.fr/file/index/docid/731245/filename/Romania_s_Post-

Cold War_International_Relations.pdf.

Chobanova, Y. (2018). Interview with H.E. Yordanka Chobanova on the Bulgarian Presidency of the Council of the EU. Retrieved from https://www.globsec.org/interview-yordanka-chobanova-bulgarian-presidencycouncil-eu/\#8HviljheiS69LDBx.99

Clark, D. \& Foxal, A. (2014) Russia's Rolein the Balkans -Cause for Concern?, The Henry Jackson Society. Retrieved from: http://henryjacksonsociety.org/wpcontent/uploads/2014/06/Russias-Role-in-the-Balkans.pdf.

Copsey, N., \& Haughton, T. (2009). The Choices for Europe: National Preferences in New and Old Member States. JCMS: Journal of Common Market Studies, 47(2), 262-286.

Copsey, N., \& Pomorska, K. (2013). The Influence of Newer Member States in the European Union: The Case of Poland and the Eastern Partnership. Europe-Asia Studies, 66(3), 421-443.

Dąborowski, T. \& Iwański, T. (2016). Breaking through distrust in relations between Romania and Ukraine, Centre for European Studies (OSW). Retrieved from https://www.osw.waw.pl/en/publikacje/analyses/2016-04-27/breaking-throughdistrust-relations-between-romania-and-ukraine.

Denca, S. (2010). European Integration and Foreign Policy in Central and Eastern Europe: The Cases of Hungary, Slovakia and Romania (Doctoraldissertation). Retrieved from http://etheses.bham.ac.uk/1462/1/Denca_11_PhD.pdf. 
Denca, S. (2013). Romania - the Black Sea Atlanticist. In M. Baun \& D. Marek (Eds.), The New Member States and the European Union. Foreign Policy and Europeanization, (pp. 175-189). London: Routledge.

European Commission (2015). Towards a New European Neighbourhood Policy. Retrieved from https://ec.europa.eu/neighbourhoodenlargement/sites/near/files/neighbourhood/consultation/consultation.pdf.

Entman, R. (1993). Framing: Toward Clarification of a Fractured Paradigm. Journal of Communication, 43(4), 51-58.

Franza, L. (2015). From South Stream to Turk Stream. Clingendael International $\begin{array}{lll}\text { Energy } & \text { Programme. } & \text { Retrieved }\end{array}$ http://www.clingendaelenergy.com/inc/upload/files/CIEP_paper_201505_web_1.pdf.

Galbreath, D. J. \& Lamoreaux, J. W. (2007). Bastion, Beacon or Bridge? Conceptualising the Baltic Logic of the EU's Neighbourhood. Geopolitics, 12(1), 109-132.

Ghinea, C. (2015). Romania. EU-28 Watch. Retrieved from http://eu-28watch.org/wpcontent/uploads/sites/3/2015/10/EU28W11_RomaniaPDF.pdf.

Gotev, G. (2013). Romania wants EU compensation for abandoned Nabucco project. Retrieved from https://www.euractiv.com/section/central-europe/news/romaniawants-eu-compensation-for-abandoned-nabucco-project/

Gotev, G. (2016). Bulgaria refutes Austrian claims of ‘joint position’ against Turkey. Euractiv. Retrieved from https://www.euractiv.com/section/enlargement/news/bulgaria-refutes-austrianclaims-of-joint-position-against-turkey/ 
Grabbe, H. (2001). How Does Europeanisation Affect CEE Governance? Conditionality, Diffusion and Diversity, Journal of European Public Policy, 8(6), 1013-1031.

Ivan, R. (2012). Black Sea Regional Leadership in Romanian Foreign Policy Discourse. In R. Ivan (Ed.), New Regionalism or No Regionalism? Emerging Regionalism in the Black Sea Area (pp. 155-172). Surrey: Ashgate Publishing.

Jakobsen, P. V. (2009), Small States, Big Influence: The Overlooked Nordic Influence on the Civilian ESDP. Journal of Common Market Studies, 47(1), 81-102.

Kesa, K. (2011), Latvian and Lithuanian Policy in the Eastern Neighbourhood: Between Solidarity and Self Promotion. Perspectives, 19(2), 81-100.

Kojouharov, A. (2004). Bulgarian 'Macedonian' Nationalism: A Conceptual Overview. OJPCR: The Online Journal of Peace and Conflict Resolution, 6(1), 282-295.

Kurečić, P. (2017). The 'New Cold Warriors' and the 'Pragmatics': The Differences in Foreign Policy Attitudes towards Russia and the Eastern Partnership States among the NATO Member States from Central and South-Eastern Europe. Croatian International Relations Review, 23(80), 61-96.

Linden, R. H. (2009). The burden of belonging: Romanian and Bulgarian foreign policy in the new era. Journal of Balkan and Near Eastern Studies, 11(3), 269-291.

Maass, M. (2009). The Elusive Definition of the Small State. International Politics, $46(1), 65-83$.

Manoli, P. (2011). black sea regionalism in perspective, Neighbourhood Policy Paper. Retrieved from: https://www.files.ethz.ch/isn/135477/NeighbourhoodPolicyPaper(02)(1).pdf

Marcussen M., Wivel A., \& Miles L. (2011). Denmark and the European Union. London: Routledge. 
Nasra, S. (2011). Governance in EU foreign policy: exploring small state influence. Journal of European Public Policy, 18(2), 164-180.

NEOnline (2017). Bulgaria's unilateral lift of Russian sanctions has always been an $\begin{array}{llll}\text { empty threat. New } & \text { Europe. } & \text { Retrieved }\end{array}$ https://www.neweurope.eu/article/bulgarias-unilateral-lift-russian-sanctionsalways-empty-threat/

Nitoiu, C. (2011). Reconceptualizing 'Cooperation' in EU-Russia Relations. Perspectives on European Politics and Society, 12 (4), 462-476.

Nitoiu, C. (2015). The EU Foreign Policy Analysis: Democratic Legitimacy, Media, and Climate Change. New York: Palgrave Macmillan.

Novinite (2010). Bulgaria Foreign Minister: EU Grows More Interested in Black Sea Region. Retrieved from https://www.novinite.com/articles/116640/Bulgaria+Foreign+Minister\%3A+EU+ $\underline{\text { Grows }+ \text { More }+ \text { Interested }+ \text { in }+ \text { Black }+ \text { Sea }+ \text { Region }}$

Novinite (2018). Radev to Putin: Bulgaria and Russia must be Frank with Each Other, 22 May. Retrieved from:

https://www.novinite.com/articles/190250/Radev+to+Putin\%3A+Bulgaria+and+R $\underline{\text { ussia }+ \text { must+be+Frank+with+Each+Other. }}$

Papadimitriou, D. and Phinnemore, D. (2004). Europeanisation, Conditionality and Domestic Change: The Twinning Exercise and Administrative Reform in Romania, Journal of Common Market Studies, 42(3), 619-639.

Pastore, G. (2013). Small new member states in the EU foreign policy: toward 'small state smart strategy?. Baltic Journal of Political Science, 2, 67-84. 
Pavlenko, V., et. al ( 2014). An Analysis of Romania's Foreign Policy Relations in the Context of Ukraine's European Integration. Lithuanian Foreign Policy Review, $31,103-24$.

Presidential Administration (2006). National Defence Strategy. Retrieved from http://old.presidency.ro/static/ordine/CSAT/SSNR.pdf.

Presidential Administration (2010). National Defence Strategy (NDS). Retrieved from http://ccpic.mai.gov.ro/docs/Strategia_nationala_de aparare.pdf

Presidential Administration (2015). National Defence Strategy. Retrieved from http://ccpic.mai.gov.ro/docs/Strategia_nationala_de_aparare.pdf.

Ralchev, S. (2015). Elusive Identity: Duality and Missed Opportunities in Bulgarian Foreign Policy in the Black Sea Region. In Shirinyan, A., \& Slavkova, L. (Eds.) Unrewarding Crossroads? The Black Sea Region amidst the European Union and Russia, (pp. 122-150). Sofia: Sofia Platform.

Rhinard, M. (2010). Framing Europe: The Policy Shaping Strategies of the European Commission. Dordrecht: Republic of Letters.

RMFA (2018a). Projects for the Black Sea region. Retrieved from https://www.mae.ro/en/node/2158.

RMFA (2018b). Dosare de actualitate. Retrieved from http://www.mae.ro/taxonomy/term/491/1.

RMFA (2018c). Romania's Position. Retrieved from https://www.mae.ro/en/node/2137. RMFA (2018d). ICJ Advisory Opinion on Kosovo. Retrieved from https://www.mae.ro/en/node/2853.

RMFA (2018e). Eastern Partnership. Retrieved from https://www.mae.ro/en/node/286.

RMFA (2018f). MAE nu recunoaşte anexarea Republicii Autonome Crimeea şi a oraşului Sevastopol. Retrieved from http://www.mae.ro/node/25483. 
RMFA (2018g). Comisia NATO-Ucraina. Retrieved from https://nato.mae.ro/node/269.

Romanian Ministry of Regional Development and Tourism (2010). Acord intre Guvernul României și Guvernul Republicii Moldova. Retrieved from https://lege5.ro/Gratuit/ge2demjzgu/acordul-intre-guvernul-romaniei-si-guvernulrepublicii-moldova-privind-implementarea-programului-de-asistenta-tehnica-sifinanciara-in-baza-unui-ajutor-financiar-nerambursabil-in-valoare-de-100milioa? $\mathrm{d}=2018-01-05$.

Romanian Supreme Defence Council (2016). Comunicat de presă. Retrieved from http://csat.presidency.ro/?pag=46\&id=14439.

Schultz, F., Kleinnijenhuis, J, Utz, S., \& van Atteveldt, W. (2012). Strategic Framing in the BP Crisis: A Semantic Network Analysis of Associative Frames. Public Relations Review, 38(1), 97-107.

Slavov, A. (2017). The Bulgarian Orthodox church - an instrument for Russian influence in the region?, Bulgaria Analytica. Retrieved from: http://bulgariaanalytica.org/en/2017/06/28/the-bulgarian-orthodoxchurch/.Thorhallsson, B. and Steinsson, S. (2017). Small State Foreign Policy, Oxford Research Encyclopedia of Politics. Retrieved from http://uni.hi.is/baldurt/files/2018/09/Small-State-Foreign-Policy-5404.pdf

Toje, A. (2010). The European Union as a Small Power: After the Post-Cold War. Basingstoke: Palgrave Macmillan.

Tsolova, T. (2017). Socialists say Bulgaria pays high price for EU's Russia sanctions. Reuters. Retrieved from: https://www.reuters.com/article/us-bulgaria-electionsocialists-idUSKBN16O1AA

Tulmets, E. (2014). East Central European Foreign Policy Identity in Perspective: Back to Europe and the EU's Neighbourhood. Basingstoke: Palgrave Macmillan. 
Väyrynen, R. (1971). On the Definition and Measurement of Small Power Status, Cooperation and Conflict, 6(2), 91-102. 